\title{
Immunogenicity of Multiple Antigen Peptides Containing Plasmodium vivax CS Epitopes in Balb/c Mice
}

\author{
Myriam A Herrera/ ${ }^{+}$, Cecilia de Plata, Jhon Mario González*, \\ Giampietro Corradin**, Sócrates Herrera
}

School of Health, Universidad del Valle, A.A. 2188 Cali, Colombia *Fundación Centro de Primates, Universidad del Valle, Cali, Colombia **Institut de Biochemie, University of Lausanne, Lausanne, Switzerland

Multiple antigen peptide systems (MAPs) allow the incorporation of various epitopes in to a single synthetic peptide immunogen. We have characterized the immune response of $B A L B / c$ mice to a series of $M A P s$ assembled with different $B$ and $T$ cell epitopes derived from the Plasmodium vivax circumsporozoite (CS) protein. A B-cell epitope from the central repeat domain and two $T$-cell epitopes from the amino and carboxyl flanking regions were used to assembled eight different MAPs. An additional universal $T$ cell epitope (ptt-30) from tetanus toxin protein was included. Immunogenicity in terms of antibody responses and in vitro Tlymphocyte proliferation was evaluated. MAPs containing B and T cell epitopes induced high titers of anti-peptides antibodies, which recognized the native protein on sporozoites as determined by IFAT. The antibody specificity was also determined by a competitive inhibition assay with different MAPS. A MAP containing the B cell epitope ( 111$)$ and the universal epitope ptt-30 together with another composed of p11 and the promiscuous $T$ cell epitope ( $p 25$ ) proved to be the most immunogenic. The strong antibody response and specificity for the cognate protein indicates that further studies designed to assess the potential of these proteins as human malaria vaccine candidates are warranted.

Key words: malaria - Plasmodium .vivax - vaccines - synthetic peptides

Repeated immunization with radiation-attenuated malaria sporozoites protects animals (Vanderberg et al. 1969) and humans (Clyde et al. 1975) against challenge with normal sporozoites. This immunization procedure induces a strong antibody response mainly directed against the central repeat domain of the $\mathrm{CS}$ proteins. $\mathrm{T}$ cell responses are induced by several epitopes located throughout the CS protein (Nardin \& Nussenweig 1993). Passive transfer of monoclonal antibodies specific to the Plasmodium berghei CS protein have partially or totally protected mice against sporozoite challenge (Potocnjak et al. 1980, Egan et al. 1987) and monoclonal antibodies against the repeat regions of both $P$. falciparum and $P$. vivax were able to neutralize and abolish their infectivity in vitro (Hollingdale et al. 1982). In addition, complete protection was also obtained by passive transfer of murine CS-

\footnotetext{
This investigation received financial support from the UNDP/WORLD BANK/WHO Special Programme for Research and Training in Tropical Diseases (TDR), The Fondo Colombiano de Investigaciones Cientificas y Proyectos Especiales "Francisco José de Caldas" (COLCIENCIAS) and from the Fundación para la Educación Superior (Fundación FES).

+Corresponding author
}

specific cytotoxic lymphocyte (CTL) clones (Kumar et al. 1988, Romero et al. 1989), whereas $\mathrm{T}$-cell depletion of mice rendered the animals completely susceptible to sporozoite challenge (Weiss et al. 1988). Because of this evidence for the possibility to prevent malaria infection by sporozoite immunization, efforts have focused on the development of a sporozoite-based vaccine for humans. Several vaccine trials have been carried out in human volunteers using both recombinant and synthetic peptides based on an immunogenic B cell epitope located in the CS repeat domain. These trials however were shown to confer limited protection (Ballou et al. 1987, Herrington et al. 1987).

The recent development of the Multiple Antigen Peptide systems (MAPs) allows the incorporation of multiple $B$ and $T$ cell epitopes in a single immunogenic macromolecule (Tam 1988). MAPs containing multiple copies of the immunodominant B-cell epitope plus a T-helper cell (Th) epitope or the Th epitope alone, all from the $P$. berghei CS protein have recently shown the capacity to induce high titers of anti-sporozoite antibodies and to significantly protect immunized mice (Tam et al. 1990, 
Migliorini et al. 1993). Although the role played by these antibodies seems to be important, antibodies against other regions of the CS protein (Franke et al. 1992) as well as efficient helper and CTL epitopes could be required to induce functional protective responses in vivo. In the search for such protective human $\mathrm{B}$ and $\mathrm{T}$-cell epitopes, the responses of immune individuals to the P.vivax CS protein have been studied (Herrera et al. 1992).

Herein we assessed the immunogenicity of a series of MAPs containing B and/or T-cell epitopes of the $P$. vivax CS protein. Antibody responses to each synthetic MAP and to the native protein as well as in vitro $\mathrm{T}$ cell proliferation were evaluated in $\mathrm{BALB} / \mathrm{c}$ mice.

\section{MATERIALS AND METHODS}

\section{SYNTHETIC PEPTIDES}

Eight tetra-branched MAPs were synthesized on a core of three lysines separated by glycine residues as described elsewhere (Tam 1988). Each of the MAPs contained branches based on dimer or trimer of $T$ and $B$ cell epitopes (group B and $T$ ) or combinations of thereof (group $B+T$ ) that have been previously shown to correspond to epitopes recognized by human T cells (Herrera et al. 1992) or immune sera (Herrera et al. in preparation). Peptide 11 (p11) is located within the central B-cell domain and was included as a B-cell epitope in these MAPs. Two other sequences that map either the amino (p6) or the carboxyl ( $\mathrm{p} 25$ ) flanking regions were included as T-cell epitopes. An additional T-cell epitope (ptt30) derived from the tetanus toxin (Panina-Bordignon et al. 1989) was included in some of the MAPs (Table I). The same linear epitopes synthesized by the F-moc solid phase technique (Atherton et al. 1981) were used for the in vitro tests.

Mice immunization - Six-week-old BALB/c mice ( 3 mice/group) were immunized s.c. at the base of the tail with $50 \mu \mathrm{g} / \mathrm{ml}$ of each MAP diluted in PBS and emulsified in CFA on days 0 and 20. Mice were bled and sera were collected on day 10 after the second immunization and stored frozen at $-70^{\circ} \mathrm{C}$ until use.

Antibody response - The humoral immune response to the MAPs was measured by an ELISA test. Flexible 96-well microtiter plates (Falcon3911) were coated with different concentrations of each MAP diluted in PBS and incubated overnight at $4^{\circ} \mathrm{C}$. Plates were blocked with $1 \% \mathrm{BSA}$ in PBS

\section{TABLE I}

Composition of the Multiple Antigen Peptides (MAPs). Group B compose of MAP I and II containg a monoepitopic B cell epitope p11. Group T compose of MAP III - V are mono or diepitopic based on T cell epitopes p6, p25 and p-tt30. Group B+T, MAPs VI, VII and VIII assembled with combinations of the all $B$ and T cell epitopes (p6, p11, p25 and $\mathrm{ptt} 30$ )

\begin{tabular}{ccl}
\hline $\begin{array}{c}\text { Epitope } \\
\text { group }\end{array}$ & $\begin{array}{c}\text { MAP } \\
\text { code }\end{array}$ & \multicolumn{1}{c}{ construct } \\
\hline B & I & p112x \\
& II & p113x \\
& III & p25(1x) \\
T & IV & ptt-30(1x) \\
& V & p25(1x)-p6(1x) \\
& VI & p11(3x)-p25(1x) \\
B+T & VII & p11(3x)-p30(1x) \\
& VIII & p11(3x)-p25(1x)-p6(1x) \\
\hline
\end{tabular}

for 1 hour at $25^{\circ} \mathrm{C}$. After several washes, serial dilutions of test and control sera in PBS-1\% BSA$0.05 \%$ Tween 20 were added and incubated once more for 1 hour at room temperature. Each serum was tested against all the MAPs. Plates were further incubated in the presence of horseradish peroxidaseconjugated goat antimouse IgG (Sigma, St. Louis MO) for 1 hour at $25^{\circ} \mathrm{C}$. After washing, $100 \mu \mathrm{l}$ of $\mathrm{O}$-phenylenediamine $(400 \mathrm{ug} / 1 \mathrm{ml}$ citrate buffer $\mathrm{pH}$ 5.0) substrate containing $0.05 \% \mathrm{H}_{2} \mathrm{O}_{2}$ were added and incubated for $1 \mathrm{~h}$. Absorbance was read at 492 $\mathrm{nm}$ in a Titertek Multiskan reader (Flow Laboratories, McLean, VA). Specificity of the antibody response was evaluated by a competitive inhibition assay (Shi et al. 1993). The 50\% binding point dilution was established with a pool of sera from mice immunized with MAP VII. The pool was diluted $1 / 10,000$ and adsorbed with several concentrations $(0.001,0.1,1,10$ and $20 \mu \mathrm{g} / \mathrm{ml})$ of the related MAPs II, III, IV and witn an unrelated MAP made from $P$. falciparum MSP-1 epitopes. The ELISA test was completed as described above.

The presence of anti-sporozoite antibodies was determined by an indirect immunofluorescence assay (IFAT) as previously described (Ballou et al. 1987). Air-dried $P$.vivax sporozoites containing the classical repeat sequence of the CS protein (Arnot et al. 1985) were incubated with two-fold dilutions 
of mouse sera and antibody titers were determined with an fluorescein isothiocyanate (FITC) conjugate anti-mouse IgG (Sigma, St. Louis MO). Titers are expressed as the reciprocal of the last serum dilution showing positive fluorescence.

Lymphocyte Proliferation Assay - Inguinal and periaortic lymph node cells (LN) were obtained prior to immunization or 20 days after the booster dose and an in vitro $\mathrm{T}$ cell proliferation test was performed as described elsewhere (Herrera et al. 1992).

\section{RESULTS}

\section{ANTIBODY RESPONSES}

MAPs I and II (group B) that contained only the $B$ cell epitope ( $p 11)$ assembled as a dimer or trimer were not immunogenic. Sera from animals immunized with these two MAPs did not recognize the homologous peptide nor any other MAP construct containing the same epitopes, however they were able to induce in vitro $\mathrm{T}$-cell proliferative responses. Although MAPs III-V (group T) based on individual or combined $\mathrm{T}$ cell epitopes were not expected to induce antibody production, all three constructs were recognized by the sera of mice immunized with the corresponding molecules or with MAPs containing the same epitopes, except for MAP IV. Mice immunized with MAPs VI-VIII (group B+T) were the most immunogenic. All sera of this group reacted with their corresponding MAP as well as with the others containing the same epitopes. Surprisingly, sera of animals immunized with MAP VI composed of p11-p25 were able to recognized MAP VII containing of p11-p30 whereas they did not recognize other MAPs that contained these two epitopes, i.e., MAPs I, II, IV (Table II).

Antibody titers determined for all positive sera are shown in Table III. Titers ranged from $1 / 100$ to $1 / 80,000$. Sera from all animals immunized with MAPs included in groups B and B+T were able to recognize the homologous synthetic molecule yet only antisera to MAPs VI-VIII reacted with the native CS protein by IFAT. Sera from mice immunized with MAP VII showed the highest antibody titer by ELISA and the best recognition of the cognate antigen. The competition assays performed with this serum indicated that although this construct elicited mainly specific antibodies, the cross

TABLE II

Presence of antibodies in sera of BALB/c mice immunized with MAPs by ELISA technique. Serum were diluted 1/100 and tested in microtiter plates coated with the different MAPs. Samples were considered positive when absorbance was above the mean of pre-immunization $\mathrm{OD}_{492}$ plus $3 \mathrm{SD}^{\mathrm{a}}$. Negative sera were used to determine the cutoff value: 0.212

OD492 BALB/c mice immunized with MAPs

\begin{tabular}{|c|c|c|c|c|c|c|c|c|c|}
\hline \multirow{2}{*}{$\begin{array}{l}\text { Epitope } \\
\text { Group }\end{array}$} & \multirow{2}{*}{$\begin{array}{c}\text { Immunogen } \\
\text { MAP }\end{array}$} & \multicolumn{8}{|c|}{ Coating MAPs } \\
\hline & & $\begin{array}{c}\text { I } \\
\text { p1I } 2 x\end{array}$ & $\begin{array}{c}\text { II } \\
\text { p11 3x }\end{array}$ & $\begin{array}{l}\text { III } \\
\text { p25 }\end{array}$ & $\begin{array}{l}\text { IV } \\
\text { p30 }\end{array}$ & $\begin{array}{c}\mathrm{V} \\
\mathrm{p} 25-6\end{array}$ & $\begin{array}{c}\text { VI } \\
\text { p11-25 }\end{array}$ & $\begin{array}{c}\text { VII } \\
\text { p11-30 }\end{array}$ & $\begin{array}{c}\text { VIII } \\
\text { p11-25-6 }\end{array}$ \\
\hline \multirow{3}{*}{ B } & I & 0.080 & 0.128 & 0.103 & 0.155 & 0.082 & 0.125 & 0.180 & 0.107 \\
\hline & II & 0.148 & 0.156 & 0.163 & 0.107 & 0.095 & 0.131 & 0.105 & 0.115 \\
\hline & III & 0.075 & 0.097 & 0.541 & 0.122 & 0.256 & 0.100 & 0.065 & 0.063 \\
\hline \multirow[t]{3}{*}{$\mathrm{T}$} & IV & 0.098 & 0.087 & 0.145 & $>2.0$ & 0.080 & 0.094 & 0.039 & 0.078 \\
\hline & V & 0.044 & 0.095 & $>2.0$ & 0.120 & $>2.0$ & $>2.0$ & 0.039 & $>2.0$ \\
\hline & VI & 0.106 & 0.065 & 1.206 & 0.156 & 0.149 & $>2.0$ & 0.500 & 0.946 \\
\hline \multirow{3}{*}{$B+T$} & VII & 0.179 & 1.742 & 1.168 & $>2.0$ & 0.191 & $>2.0$ & $>2.0$ & $>2.0$ \\
\hline & VIII & 0.061 & 0.131 & $>\mathbf{2 . 0}$ & 0.073 & $>\mathbf{2 . 0}$ & 0.707 & 1.250 & $>2.0$ \\
\hline & Control $^{\mathrm{a}}$ & 0.041 & 0.167 & 0.082 & 0.131 & 0.094 & 0.134 & 0.167 & 0.153 \\
\hline
\end{tabular}


TABLE III

Titer and specificity of IgG antibody by ELISA and IFAT test in mouse sera. Values are the reciprocal of the highest positive antibody dilution. The ELISA titers are expressed as the reciprocal of the last positive deletion $\times 10^{-3}$

\begin{tabular}{|c|c|c|c|c|c|c|c|c|c|c|}
\hline \multirow{3}{*}{$\begin{array}{l}\text { Epitope } \\
\text { group }\end{array}$} & \multirow{3}{*}{$\begin{array}{c}\text { Immunogen } \\
\text { MAP }\end{array}$} & \multirow[b]{3}{*}{ I } & \multicolumn{4}{|c|}{ Antibody titer in immunized mice } & & & & \\
\hline & & & & \multirow[b]{2}{*}{ III } & \multicolumn{2}{|c|}{ Coating MAPs } & \multirow[b]{2}{*}{ VI } & \multirow[b]{2}{*}{ VII } & \multirow[b]{2}{*}{ VIII } & $\begin{array}{c}\text { IFAT } \\
\text { titer }\end{array}$ \\
\hline & & & II & & IV & $\mathrm{V}$ & & & & \\
\hline \multirow{2}{*}{ B } & 1 & 0 & 0 & 0 & 0 & 0 & 0 & 0 & 0 & 0 \\
\hline & II & 0 & 0 & 0 & 0 & 0 & 0 & 0 & 0 & 0 \\
\hline \multirow{3}{*}{$\mathrm{T}$} & III & 0 & 0 & 0.5 & 0 & 0.1 & 0 & 0 & 0 & 0 \\
\hline & IV & 0 & 0 & 0 & 40 & 0 & 0 & 0 & 0 & 0 \\
\hline & V & 0 & 0 & 40 & 0 & 40 & 40 & 0 & 40 & 0 \\
\hline \multirow{3}{*}{$\mathrm{B}+\mathrm{T}$} & VI & 0 & 0 & 10 & 0 & 0 & 40 & 0.5 & 5 & 80 \\
\hline & VII & 0 & 20 & 10 & 40 & 0 & 40 & 80 & 40 & 1260 \\
\hline & VIII & 0 & 0 & 40 & 0 & 40 & 1 & 10 & 40 & 10 \\
\hline
\end{tabular}

reaction observed with other MAPs was absorbed with those molecules (Fig 1).

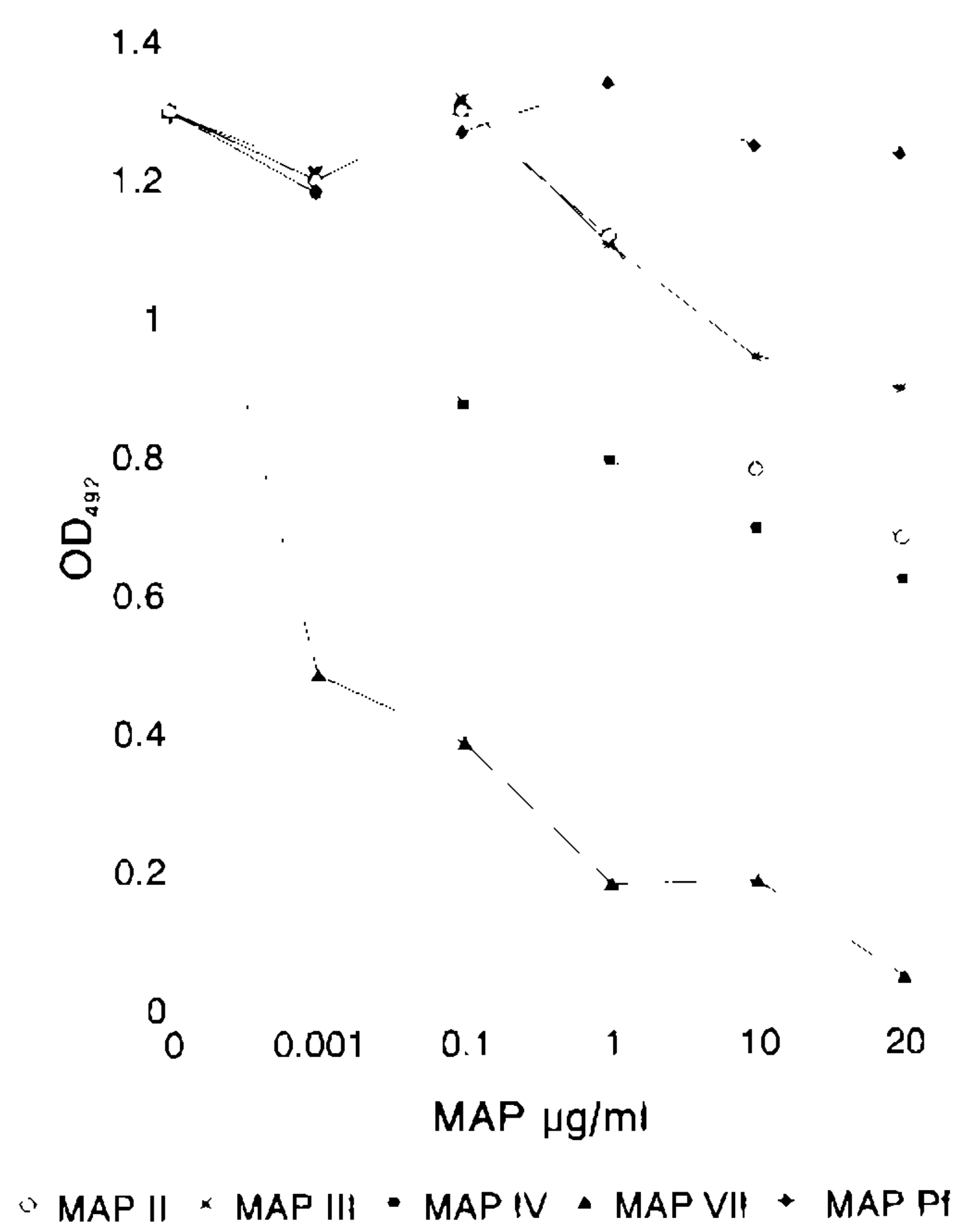

Fig. 1: competitive MAP inhibition assay. Sera of mice immunized with MAP VII .

\section{T CELL PROIJfERATION}

Table IV shows the in vitro proliferative T-cell responses induced by MAP constructs and the individual epitopes. All cultures stimulated with MAPs showed uniformly low responses and only MAPS VI-VIII induced moderately positive stimulation indexes. When individual peptides were used, only p1 1 and p 25 induced proliferation of cells from mice immunized with MAP I and VI. All other animals presented negative in vitro proliferation responses.

\section{DISCUSSION}

The P.vivax CS epitopes used to assemble the MAPs studied in the present experiment were selected because of their documented reactivity with T lymphocytes (Herrera et al. 1992) and antibodies from malaria immune donors. The universal $\mathrm{T}$ cell epitope from the Tetanus toxin is routinely recognized by murine and human cells (Panina-Bordignon et al. 1989).

Our previous studies indicated that the $\mathrm{T}$ cell epitope contained in the $\mathrm{p} 6$ peptide induced strong in vitro $\mathrm{T}$ cell proliferative response although its recognition was rather restricted to a limited number of human donors (Herrera et al. 1992). In contrast, p25 was broadly recognized by a wide range of 
TABLE IV

Stimulation indexes (SI) of lymph node cells from each BALB/c mouse after stimulation with 100,10 and $1 \mu \mathrm{g} / \mathrm{ml}$ of each MAPs or $10 \mu \mathrm{g} / \mathrm{ml}$ of their corresponding individual peptide. Values above 3 SI are considered positive

\begin{tabular}{|c|c|c|c|c|c|c|c|c|}
\hline \multirow{2}{*}{$\begin{array}{l}\text { Epitope } \\
\text { group }\end{array}$} & \multirow{2}{*}{$\begin{array}{l}\text { Immunogen } \\
\text { MAP }\end{array}$} & \multicolumn{3}{|c|}{$\mathrm{MAPS} \mu \mathrm{g} / \mathrm{ml}$} & \multicolumn{4}{|c|}{ Individual Peptides $10 \mu \mathrm{g} / \mathrm{ml}$} \\
\hline & & 100 & 10 & 1 & p6 & $\mathrm{pl1}$ & $\overline{p 25}$ & $\mathrm{p} 30$ \\
\hline \multirow[t]{2}{*}{ B } & I & 1.3 & 1.3 & $\overline{1.9}$ & - & 4.6 & - & - \\
\hline & II & 0.5 & 0.2 & 1.8 & - & 1.9 & - & - \\
\hline \multirow[t]{3}{*}{$\mathrm{T}$} & III & 0.5 & 0.9 & 0.6 & - & - & 0.5 & - \\
\hline & IV & 1.1 & 2.2 & 2.4 & - & - & - & 1.6 \\
\hline & $\mathrm{v}$ & 0.8 & 1.0 & 1.0 & - & - & 1.6 & 1.0 \\
\hline \multirow[t]{3}{*}{$\mathrm{B}+\mathrm{T}$} & $\mathrm{VI}$ & 2.4 & 2.7 & 6.4 & - & 9.8 & 17.4 & - \\
\hline & VII & 4.9 & 1.3 & 1.6 & - & 2.1 & - & 1.8 \\
\hline & VIII & 4.0 & 1.7 & 1.3 & 1.8 & 2.4 & 2.0 & - \\
\hline
\end{tabular}

donors but its proliferative response was moderate. pll was included in the present study as a B cell epitope since it is recognized by most sera from immune individuals from endemic areas that also react with the human CS protein. Apart of its B cell function, this peptide also behaves as $\mathrm{T}$ cell epitope (Herrera et al. 1992, Nardin et al. 1991).

Due to the limited knowledge regarding optimal MAPs structure, we decided to assemble molecules of different $\mathrm{B}$ and $\mathbf{T}$-cell epitopes combination as well as control MAPs containing only $B$ or $T$ cell epitopes. As expected the constructs based on combinations of $\mathrm{B}$ and $\mathrm{T}$ cell epitopes were highly immunogenic. Most of them induced high antibody titers after only 2 immunization doses. All three MAPs (VI-VIII) were strongly recognized by sera of mice immunized with the homologous peptides, and these sera reacted with the same peptides assembled in different constructs. Interestingly, MAP VI based on the combination of $\mathrm{p} 11$ and $\mathrm{p} 25$ elicited antibodies that recognized p 25 but apparently not p1 1 at least not when assembled as a monoepitopic construct (MAP I-II). MAP VII induced the strongest antibody response and these antibodies reacted with several different MAPs including some composed of unrelated epitopes. Although sera against all three MAPs $(B+T)$ recognized the native protein by IFAT, serum against MAP VII produced the strongest reaction.

These results suggest that although MAP systems are capable of inducing high antibody responses, at least a fraction of these antibodies may be directed against non revelants sequences. P25 and ptt-30 do not share any sequence homology, however MAPs containing these two epitopes induce cross-reactive antibodies. In fact, the competition assay demonstrated that the other MAPs to which this serum was reactive were only capable of partially compete with the homologous MAP VII. The fact that neither the MAP constructs nor the individual epitopes were able to elicit a strong proliferative response in vitro does not reflect the in vivo situation as the vigorous $B$ cell response against the multiepitopic MAPs as compared to the poor response to $B$ cell monoepitopies can only be explained by a strong $T$ helper reaction. As expected MAPs constructs based on either B or $\mathbf{T}$ cell epitopes alone were very poor immunogens. MAPs I-II based exclusively on the p11 B-cell epitope did not induce detectable antibodies, whereas MAPs III-V based on T-cell epitopes induced some anti-peptide antibodies.

In conclusion, we have confirmed the high immunogenicity of the MAP systems containing both $B$ and $T$ cell epitopes and have identified at least two combinations of B-T epitopes that may have the potential of inducing protective immune responses to P.vivax infection. Although, p25 produced a good helper response, the MAP VII containing ptt30 was the most immunogenic. This confirms the great potential of ptt30 as $\mathrm{T}$ helper epitope. Experiments designed to determine the protective efficacy of such MAPs in non-human primates are currently in progress. 


\section{REFERENCES}

Arnot DE, Barnwell JW, Tam JP, Nussenzweig V, Nussenzweig RS, Enea V 1985. Circumsporozoite protein of Plasmodium vivax: gene cloning and characterization of the immunodominant epitope. Science 230: 815-818.

Atherton E, Logan CJ, Sheppard RC 1981. Peptide synthesis. Part 2. Procedures for solid synthesis using $\mathrm{N}$-fluorenyl methoxy carbamylamino-acid on polyamide supports. Synthesis of substance $P$ and acyl carrier protein 65-74 decapeptide. J Chem Soc Perkin Trans 1: 538-548

Ballou WR, Hoffman SL, Sherwood JA, Hollingdale MR, Neva FA, Hockmeyer WT, Gordon DM, Schneider I, Wirtz RA, Young JF, Wasserman G, Reeve FP, Digg CL, Chulay JD 1987. Safety and efficacy of a recombinant DNA Plasmodium falciparum sporozoite vaccine. Lancet 1: 1277-1281.

Clyde DF, McCarthy VC, Miller RM, Woodward WE 1975. Immunization of man against falciparum and vivax malaria by use of attenuated sporozoites. $A m J$ Trop Med Hyg 24: 397-401.

Egan JE, Weber JL, Ballou WR, Hollingdale MR, Majarian WR, Gordon DM, Maloy WL, Hoffman SL, Wirtz RA, Schneider I, Woollett GR, Young JF, Hockmeyer WT 1987. Efficacy of murine malaria sporozoite vaccines: implications for human vaccine development. Science 236: 453-456.

Franke E, Lucas CM, Chauca G, Wirtz RA, Hinestroza $S$ 1992. Antibody response to the circumsporozoite protein of Plasmodium vivax in naturally infected humans. Am Trop Med Hyg 43: 320-326.

Herrera S, Escobar P, De Plata C, Avila GI, Corradin G, Herrera MA 1992. Human recognition of $T$ cell epitopes on the Plasmodium vivax circumsporozoite protein. J Immunol 148: 3986-3990.

Herrington DA, Clyde DF, Losonsky G, Cortesia M, Murphy JR, Davis J, Baqar S, Felix AM, Heimer EP, Gillisen D, Nardin E, Nussenzweig R, Nussenzweig V, Hollingdale MR, Levine M 1987. Safety and immunogenicity in man of a synthetic peptide malaria vaccine against Plasmodium falciparum sporozoite. Nature 328: 257-259.

Hollingdale MR, Zavala F, Nussenzweig RS, Nussenzweig V 1982. Antibodies to the protective antigen of Plasmodium berghei sporozoites prevent entry into cultured cells. J Immunol 128: 1929-1930.

Kumar S, Miller LH, Quakyi IA, Keister DB, Houghten RA, Maloy WL, Moss B, Berzofsky JA, Good MF 1988. Cytotoxic T cells specific for the circumsporozoite protein of Plasmodium falciparum. Nature 334: 258-260.

Migliorini P, Betschart B, Corradin G 1993. Malaria vaccine immunization of mice with a synthetic $\mathrm{T}$ cell epitope alone leads to protective immunity. Eur $J$ Immunol 23: 582-585.

Nardin EH, Nussenzweig V, Nussenzweig RS, Collins WE, Harinasuta KT, Tapchisri $O$, Chomcharm Y 1982. Circumsporozoite protein of human malaria parasites Plasmodium falciparum and vivax. $J$ Exp Med 156: 20-30.

Nardin EH, Clavijo P, Mons B, Belkum van A, Ponnudurai T, Nussenzweig R 1991. T cell epitopes of the circumsporozoite protein of Plasmodium vivax: recognition by lymphocytes of a sporozoite-immunized chimpanzee $J$ Exp Immunol 146: 1674-1678.

Nardin EH, Nussenzweig RS 1993. T cell responses to pre-erythrocytic stages of malaria: role in protection and vaccine development against pre- erythrocytic stages. Annu Rev Immunol 11: 687-727.

Panina-Bordignon P, Tan A, Termijtelen A, Demotz S, Corradin G, Lanzavecchia A 1989. Universally immunogenic $\mathrm{T}$ cell epitopes: promiscuous binding to human MHC class II and promiscuous recognition by T cells. Eur J Immunol 19: 2237-2242.

Potocnjak P, Yoshida N, Nussenzweig RS, Nussenzweig V 1980. Monovalent fragments (Fab) of monoclonal antibodies to a sporozoite surface antigen (Pb44) protect mice against malarial infection. $J$ Exp Med 151: 1504-1513.

Romero P, Maryanski JL, Corradin G, Nussenzweig R, Nussenzweig V, Zavala F 1989. Cloned cytotoxic T cells recognize an epitope in the circumsporozoite protein and protect against malaria. Nature 341: 323 326.

Shi YP, Udhayakumar V, Alpers MA, Povoa MM, Oloo AJ, Ruebush II TK, Lal AA 1993. Natural antibody responses against the non-repeat-sequence-based $B$ cell epitopes of the Plasmodium falciparum circumsporozoite protein. Infec Immun 61: 2425-2433.

Tam JP 1988. Synthetic peptide vaccine design: synthesis and properties of a high-density multiple antigen system. Proc Natl Acad Sci USA 85: 5409-5413.

Tam JP, Clavijo P, Lu YA, Nussenzweig V, Nussenzweig $R$, Zavala $F 1990$. Incorporation of $T$ and $B$ epitopes of the circumsporozoite protein in a chemically defined synthetic vaccine against malaria. $J$ Exp Med 171: 299-306.

Vanderberg JP, Nussenzweig R, Most H 1967. Protective immunity produced by the bite of $\mathrm{X}$-irradiated infected mosquitos with Plasmodium berghei. J Parasitol 56: 350-351.

Weiss WR, Segedah M, Beaudoin RL, Miller LH, Good MF 1988. $\mathrm{CD} 8^{+} \mathrm{T}$ cell (cytotoxic/suppressor) are required for protection in mice immunized with malaria sporozoites. Proc Natl Acad Sci USA 85: 573575. 